\title{
Shifting Epistemology of Juvenile Justice in India
}

\section{Shailesh Kumar ${ }^{*}$}

\begin{abstract}
The conception of juvenile justice has its ontological root in the internationalisation of childhood and construction of children as a distinct social class. The Euro-centric vision of children as rights-possessors that informed the United Nations Convention on the Rights of the Child (CRC) (1989) transformed the epistemology of juvenile justice. India ratified the CRC in 1992, and defined 'child' uniformly, irrespective of sex, unlike in the past, thereby challenging its gendered subjectivity of 'female child.' Such an emergence of a new modality of delivering juvenile justice that I see as the epistemic shift did not last long, and one gory incident, alongside mediatised demonisation of male children, and brewing social discontent on women's safety, changed its landscape. This paper foregrounds an analysis of the role of gender in juvenile justice jurisprudence from the colonial period to the present time. Reflecting on the populist punitiveness at play, it talks about the Indian state's poverty of understanding of children's rights. Mapping legislative, juridical and political dimensions of the journey of the juvenile justice framework in India, the paper shows how construction of gendered notions of a particular group of male child offenders has resulted in the punitive turn of the juvenile justice system in India. It further unpacks the potentiality of repercussions of such punitiveness, and offers reasons as to why a retributive response by the state is a step backwards in reforming juvenile delinquents. Overall, it narrates the story of a political-systemic failure to deal with an important social issue, which may act as a lesson to be learnt with respect to the child governance framework, both for the countries in South Asia and the wider global South.
\end{abstract}

Keywords: juvenile justice; male child offender; India; populist punitiveness; gender bias; Supreme Court of India; serious offence.

\section{Introduction}

Indian legislative pro-activeness for child rights ${ }^{1}$ has led to a flurry of legislation in the twenty-first century. ${ }^{2}$ The reasons could be two-fold. The first is an enhanced global awareness pertaining to children, and a shift from the 'welfare' regime to the 'rights' regime (Kumari 2004). This shift seems to be the result of invocation of twentieth-century international legal instruments ${ }^{3}$ by both policy-makers and the judiciary in India (Thukral and Asthana 2015). The second appears to be an upward movement in registration of

\footnotetext{
* Birkbeck University of London School of Law, London, United Kingdom of Great Britain and Northern
} Ireland; shaileshk.jnu@gmail.com. ORCID iD 0000-0002-7820-0518. 
criminal offences against women and children. The former finds its root in the global construction of 'child'4 and 'childhood' as a social category and stage of life respectively that are distinct from those of an adult and adulthood, and the recognition of a child as a 'possessor' of human rights (Verhellen 2015). The latter could be a product of an amalgam of modernity and post-modernity resulting in social disciplining, commodification of human life, everyday disequilibrium (Morrison 1995) and an ever-widening economic gap in India (O'Kane 2002). Both these factors certainly resonate with the countries of South Asia, and more broadly the global South (Dados and Connell 2012), ${ }^{5}$ which are marred by their peculiar colonial history and an unequal 'developmental growth.'

This paper attempts to understand the ontological dimensions of the conceptions of 'juvenility,' 'juvenile justice' (JJ) and 'juvenile justice system' (JJS) at the intersection of 'sex,' 'gender,' 'age,' and, borrowing from Duff et al (2004), the 'normative theory of trial.' Two more variables that will gain significance as this paper moves forward are the 'nature of offence' and the 'background of offender' To highlight the significance of protecting children's rights in India, it should be sufficient to state that India is home to one-fifth of all children globally. Acknowledging their plight in a country from 'the global South, my intention here, therefore, is to engender a discussion around the epistemic shifts that have occurred in the legislative framework of JJS in India, and its translation into the JJA 2015. I will trace its lineage from the colonial till the present time, in relation to what I call a prejudiced and stereotypical construction of sex, gender and age, and the rise of what Newburn (1997) termed penal populism.

The paper is informed by the epistemology of juvenile justice and how it has changed in the contexts of time and socio-political space. Rather than merely reflecting superficiality, the use of 'epistemology' in the title has substantive meaning. It raises multiple legal quandaries that the Indian state and society were, are, and perhaps, will be confronting with respect to its juvenile delinquents, disputes enmeshed in their age and nature of offence and the JJS. Two primary epistemological questions, therefore, ensue here. What are the epistemic factors that contribute to the understanding of juvenile justice? And how critically, under what circumstances, and through what normative theorisation of crime and criminal trial can we explore these factors?

They lead to numerous secondary questions. Why should a child committing any crime be treated differently than an adult? Should a child committing a serious crime be treated differently than other child delinquents? What is the need to have a definite age of criminal responsibility? Do sex and gender play a role in trying juvenile delinquents differently? The title of the paper appeals to the idea that the conception of JJS as a separate and distinct institution of justice system from the adult criminal justice system (CJS) may require encountering these questions.

Reflecting on the journey of the Indian JJS, particularly 'child delinquency', both in the colonial and post-colonial period, the paper suggests an intertwined relationship of JJS with gender, age, and nature of offence, along with the constructive and disruptive role played by the Indian judiciary. It informs about the journey of the JJS in the context of its subjects, jurisdictional scope, socio-legal cultures, trial procedures, related institutions 
and punishments. It foregrounds an analysis of the response of the Indian state to 'violent' juvenile offenders, and its poverty of understanding of children's rights, beside the construction of gendered notions of child delinquents.

The paper highlights the state's appreciation of brewing populist punitiveness in the aftermath of the gory incident of December 2012. It explores the trigger role the incident played together with the Indian media (Kumari 2015), alongside the social movements for women's safety, in the demonisation of the community of male children. It unpacks the potential repercussions of the state's action of targeting children of the 'sixteen to eighteen' years' age group as a political tool. I also explore the likely reasons for the Indian state to target this group, and the seemingly discomforting absence of public anger at such action. Examining the recent statistics, I argue against pitching children into the rigid and violent adult CJS.

I submit a four-pronged argument, thereby demanding an urgent critical assessment and amendment of the JJA 2015, which, I argue, is a manifestation of a political rather than a social and normative take on the policy shift to reform JJS. My arguments are: first, that the JJA 2015 contradicts its own objective, and that of the national and international instruments, in letter and spirit; second, that it undoes the distance India has travelled towards securing an improved JJS; third, that it reinforces the populist perception of a 'zerosum' relationship between victims' and defendants' rights and puts a particular group of child delinquents into the violent adult adversarial criminal trial process without realising their victimhood; and fourth, that it reflects badly on us as a modern social and political community that should step towards reformative and not retributive forms of justice so as to offer the opportunity to delinquent children for social integration.

The paper has seven sections. This section, while introducing the paper, lays out its main arguments. The second section traces the lineage of child delinquency in colonial India. In the third section, I examine the twentieth-century national and international debates on JJ. In the fourth section, I discuss the legislative and juridical takes on the issue of JJ in twenty-first century India. The fifth section critically examines the JJA 2015, the reasons behind its birth, and its repercussions. The criminalising dimension of JJA 2015 and National Crime Record Bureau (NCRB) statistics are referred to in the sixth section in order to advance the argument against the classification of children based on their age and nature of offences committed by them. The entire paper is summed up thereafter with the recommendation for urgent discontinuation of retributive justice for children. Overall, the paper illustrates how gender has been sewn into JJ jurisprudence.

\section{Gender and the colonial lineage of child delinquency}

Though criminological theories were gender neutral as theories of 'crime' and 'criminality' (Morrison 1995), the discourse of criminology and gender could not remain behind the curtains as criminological literature on gender and crime came to the fore through sociologists and feminists. At its root was the distinction between 'sex' and 'gender' that gave birth to the notions of masculinity and femininity, the social constructs of gender. Where 
masculinity is linked to machismo, femininity is linked to effeminacy. This is the reason that being 'masculine' is something more than just being a 'man', and being 'feminine' is more than being a 'woman.' They require certain codes of conduct and traits which are very distinct from their presumably ascribed biological sex, and therefore, are not defined merely by genitals (Boise 2013). In this context, Horrocks (1994: 2) argues that 'gender is a structural phenomenon: that is, the masculine and feminine determine each other, are in a relationship with each other' and, hence, 'masculinity cannot [...] be viewed as an isolated phenomenon.'

Child delinquency debates, though, might seem to relate more to the tender age of a child, but they are as much related to gender. This should also not appear alien, considering the fact that crime, as Morrison (1995: iv) puts it, is 'an attempt of the self to create sacred moments of control, to find ways in which the self can exercise control and power in situations where power and control are all too clearly lodged outside the self.' This suggests a causal link between crime and criminogenic situations produced through sites of power hierarchies within socio-political edifices, from which children cannot be detached. And in the colonial context, children acted as potential future colonial subjects. Juvenile offenders, therefore, were not unseen in colonial India. The evolution of the JJ framework during the latter half of the nineteenth century, then, as has been argued, was a replica of the British JJ framework (Jaamdar 1995) to protect and hold children accountable for their crimes, but in a humane way, so as to value their mental capacities. However, this imitation was not in the truest sense. Perhaps the native cultural ideals combined with occidental and orientalist constructions of gender and the political agenda of colonial disciplining came into play (Sen 2004). Therefore, it was not easy for the British to adopt the Euro-centric version of JJ policies in colonial India.

Sen (2004: 84) contends that 'the parameters of child delinquency in India were both narrower and broader than those that applied in the imperial metropole.' The Indian scenario was different, in terms of the spatial distribution of juvenile delinquency, the nature of punishment meted out to juveniles, and the understanding of female juvenile delinquency (Sen 2005). Where Britain was dealing with Benthamite reformatory ideas and modern forms of criminal institutions and punishments, the British continued the pre-modern corporal punishment of flogging for juvenile delinquents in India (Kumari 2015; Sen 2004). For female child delinquency, the western gendered notion of woman was combined with the native ideology of woman. This is affirmed by Sen (2004: 85), when he states that the 'British discourse of delinquency had an established place for female children who were seen occasionally as the victims of adult/male lust but more often agents of sexual corruption' and the belief 'that the precocious sexuality of delinquent females represented a more serious threat to civilization than did delinquent boys.'

The female child delinquents, who were fewer than males, were not made part of the reformatory justice system that ensued for the males, unlike the case in Britain. As Sen (2004) mentions, they were punished with varying prison terms on conviction, put into lunatic asylums and sentenced to life in penal transportation, and young ones were even sent to the Andaman Islands where they were encouraged by the regime to marry male 
convicts. This discriminatory treatment continued as the female child delinquents were kept out of the domain of reformatory legislation that was brought to deal with child delinquency. The child delinquent was made a legal subject by the colonial government based on age and sex. The first legislation, the Apprentices Act, 1850, dealt with children in the age group of ten to eighteen years. The Act allowed magistrates and justices of the peace to 'apprentice' child delinquents to private 'masters', who might put them to work and discipline them physically. This, as per Sen (2004), was to train orphans and poor children as workers and was a pre-modern approach to tackling criminals.

In 1860, the Indian Penal Code (IPC) (India 1860, Section 82) came into force, wherein the age of criminality was kept at a low seven years, which continues to date. ${ }^{6}$ Based on the principle of doli incapax, ${ }^{7}$ it reflects the presumption of law that a child below the age of seven years has insufficient maturity of understanding to judge the nature and consequences of his conduct in question. However, this absolute presumption becomes rebuttable for children above seven and under twelve years age (India 1860, Section 83). ${ }^{8}$

Later on, through the Criminal Procedure Code, 1861, the Reformatory Schools Act, 1876 , and its amended version in 1897, judges were given discretionary power to send juvenile convicts to reformatory schools (Sen 2004). The first two Acts fixed the age to a limit from twelve to below sixteen years, which was reduced to under fifteen ${ }^{9}$ by the 1897 amendment, the reason being the belief that sixteen-year-olds were too hardened in their ways to be reformed (Kumari 2009a; Sen 2004). These Reformatory Schools Acts were not applicable to the female child delinquents in spite of activists' pressure to establish female reformatories. The reasons for this were the intolerance on the part of the natives about the institutionalisation of girls under the control of unrelated men at the precise age when they might find husbands, and also the shared conviction of the colonial administrators that rehabilitation for Indian girls meant marriage, and their incarceration would ruin their marital prospects (Sen 2004).

These were not the only gendered notions present in terms of child delinquency in colonial India. Narratives of effeminacy were also present, as Sen (2004: 89) notes:

$[\mathrm{P}]$ ractically every critic of Indian jail regimes in this period had apparently witnessed or had heard about a 'frightful demoralization' in the wards, by which they meant sexual contact between adult and juvenile convicts as well as the sexual abuse of younger children by the older boys. Like girl delinquents in England, boys in the India prisons were almost universally regarded as precociously sexual, and therefore dangerous not only to themselves and to easily tempted adults but also to the idea of reform itself. We could reasonably propose that the fear of juvenile homosexuality in prison was driven by the peculiarities of colonial gender: young boys epitomized the effeminate, sexually immature native male...

It should not, therefore, be a surprise to know that one of the requirements of the reformatory schools under the 1897 Act was the presence of means to separate inmates 
at night. This system of reforming the JJS in colonial India did not find success due to the abovementioned reasons, supported by lack of infrastructure. The struggle to control child delinquency, and the political objective of disciplining colonialism to make children potential imperial subjects so that they did not become a threat to the colonial state, continued.

It was immediately in the post-World War I period that the JJ reform took place in true sense, looking to the juvenile court being set up in Britain in 1908 as an example (Sen 2004). The Indian Jail Committee (1919-1920) brought to the fore the vital need for square trial and treatment of young offenders, and for establishing schools to prevent children from being lodged in jail (Pande 2014). Its recommendations prompted the enactment of the Children Act in Madras in 1920, which was followed by the Bengal and Bombay Acts in 1922 and 1924. Children were diverted from the CJS for the first time by establishing separate juvenile courts and the residential institutions under it, and this was followed by many other states (Kumari 2009a). With certain common features, they had different cut-off ages for children with categorisation into 'delinquent' and 'neglected,' but the use of prison was still not done away with absolutely (Kumari 2009a). Hence, varied notions of gender and age were embedded in the JJ framework of colonial India, which was also a tool for the colonial state to exercise power and discipline juveniles. Upon independence, India had to deal with the care and protection of its children and child delinquents from a different ideological perspective than under colonial rule. This period also saw spreading recognition of child victimhood in the post-World War II era from the Euro-centric location to the entire globe, leading to the passage of many international declarations and conventions.

\section{Post-colonial debates on juvenile justice in India, and the twentieth-century national and international legal framework}

Children, being considered as a special class of citizen, have always been on the radar of states as a potential object (Verhellen 2015), rather than subject, to be taken care of in a particular way. The international politics of children's rights constructing 'child' as a separate and distinct group from 'adult' dates back to the Geneva Declaration of the Rights of the Child, $1924 .{ }^{10}$ The macro-definition of children as 'not-yet' human beings and their status as an 'object' to be given rights, rather than a 'subject' possessing rights, dominated the first half of the $20^{\text {th }}$ century. Verhellen (2015) argues that even the 1959 Declaration on the Rights of the Child saw 'children' through the same lens. Thereafter, the United Nations Standard Minimum Rules for the Administration of JJ (Beijing Rules), 1985, came into being. Verhellen (2015: 49) further contends that the holistic ${ }^{11}$ childhood image, countering the paternalistic perceptions of child rights, was put in effect by the UN Convention on the Rights of the Child (CRC), 1989, wherein children were considered as rights-possessors rather than rights-seekers. The UN Rules for the Protection of Juveniles Deprived of their Liberty (UN Rules), 1990, provided further push for a concrete framework. 
In the post-colonial era, the Indian Constitution put the state under certain non-justiciable obligations with regard to children under the Directive Principles of State Policy. ${ }^{12}$ To fulfil these obligations, a provision was put in the section of fundamental rights. ${ }^{13}$ The Children Act (India 1960), a central government enactment, was passed to cater to the heads of the Union Territories (India 1960, Section 1(2)), as subject matters constituting JJ fell in the state list of the Indian Constitution (Kumari 1993). These Acts varied in their approach, and therefore, effected differential treatment to neglected and delinquent children. The former were to be dealt with by the Child Welfare Board while the latter were to be dealt with by the Children's Courts. The definition of 'child' under the Act was gender-biased. 'Child' was defined as a female aged below eighteen years and a male aged below sixteen years. This showcased a paternal state with a gendered notion of attainment of criminality, and a presumptive understanding that females need more protection than males. In debates on the Act in the parliament, it was argued that 'sixteen years was the appropriate age for granting protection, and girls needed protection for two more years in our social circumstances' (Rajya Sabha 1960). Based on a welfarism model, no access to lawyers was allowed in the proceedings before institutions of the JJS. To remove this lacuna, the Children (Amendment) Act was passed in 1978 that gave rights to lawyers before the Children Court but still not the Board.

To have a uniform JJ legislation for the whole country, and to bring the JJS framework in conformity with the Beijing Rules, the parliament enacted a law under Article 253 of the Constitution read with Entry 14 of the Union List (Kumari 1993), and the Juvenile Justice Act (JJA) (India 1986) came into effect on 1 December $1986 .{ }^{14}$ Beginning with the aspect of congeniality, and countering the social stigma attached to the legal texts, the language of the Children Act, 1960, replaced the word 'trial' in its long title with the word 'adjudication' and the term 'child' with 'juvenile.'15 'Juvenile,' however, without altering the legal status of children, has been considered as a negative term to define a young person (Kumari 1993).

'Juvenile Courts' and 'Juvenile Welfare Boards' were also set up under the JJA, 1986, which recognised for the first time what Carlen (1976) mentions as the realities of interactions in courtroom space, i.e., unsuitability of usual courtrooms for children. Hence, the sittings of the Boards and Juvenile Courts were mandated, as far as practicable, to be held in a different building or room than the usual court building/courtroom, or on different days or at times if the sitting is to held in regular courts (India 1986, Section 27(2)). Still, it was not followed due to lack of infrastructure and special training in child welfare or child psychology, keeping child justice illusive.

The Children Act, 1960 and the JJA 1986, were otherwise the same in their substance. The sex discriminatory definition of child continued (India 1986, Section 2(h)). Displaying disagreement, Kumari (1993) argues that it was discriminatory for both boys and girls in different contexts, and was also unlike other existing Indian statutes that defined child uniformly to be of less than eighteen years irrespective of sex. Law ignored the trauma of children that does not depend on age, thereby, reflecting the gender inequality prevalent in Indian society. Further, 'neglected child' (India 1960, Section 2(1)), which excluded a 
child victim of some criminal offence, was corrected by its inclusion under 'neglected juvenile' (India 1986, Section 2(1)).

There were still many flaws under the JJA 1986 that needed rectification, whether the definition of 'child, the issue related to the stage of calculating the age under the Act, bail provisions, child police units, or making child-friendly laws for delinquent children. Kumari's $(1993,2015)$ and Kulkarni's (1994) work offer a holistic understanding of these matters. In need of a more robust JJS, India ratified the CRC on 11 December 1992 (UN Treaty Collection 2018). ${ }^{16}$ The next sub-section will discuss the outcome that this ratification had on the Indian juvenile justice framework.

\section{Enter the twenty-first century: towards a robust JJS}

With a bittersweet experience from previous legislation, India entered the twenty-first century in quest of an improved, inclusive, humane and child-friendly justice system that should not be a recipe for stress and stigma. In achieving this novel goal, the Indian legislature and judiciary both played their respective roles in tandem with the executive, but where the legislative march was in the right direction, the judiciary's actions were blemished with inconsistency.

\section{Legislative deliberations: shaping up progressive understanding}

Envisaging a better justice system for children in India, in 2000, the Indian parliament enacted the JJA 2000 with the standards prescribed under the CRC, the Beijing Rules, the UN Rules and other relevant international instruments, with more emphasis on care and protection of children. ${ }^{17}$ For the first time, the term 'child' was defined as 'a person who has not completed eighteenth year of age', thereby doing away with the differential treatment of children based on sex (India 2000, Section 2(k)). However, keeping both the terms 'child' and 'juvenile' in the Act did cause confusion (Kumari 2009a). The segregated approach for the two categories of children, namely, 'juveniles in conflict with law' (JCL) and 'children in need of care and protection' (CNCP) continued. Terms like 'delinquent' and 'neglected,' as well as many other negatively connoted terms like 'arrest,' 'trial,' 'police' and 'jail' were replaced.

It abolished the 'Juvenile Courts', keeping only the 'Juvenile Justice Board,' and mentioned the 'adoption of a child-friendly approach in the adjudication process' (Madras High Court 2012), ${ }^{18}$ though without defining what 'child-friendly' actually means. The Board consisted of a Metropolitan Magistrate or a Judicial Magistrate of the first class, and two social workers of which at least one should be a woman (India 2000, Section $4(2))$. This was the first time a pre-condition for appointment was brought in, whereby the Magistrate was required to have special knowledge or training in child psychology or child welfare to become a Board member (India 2000, Section 4(3)). Further, the assistive role of social workers in the Juvenile Courts under the JJA 1986 was transformed into the full-fledged role of Board members, and they also have had active involvement in health, 
education or welfare activities pertaining to children for at least seven years (India 2000, Section 4(3)).

This Act prohibited the joint trial of a juvenile with a non-juvenile, thereby mandating the separate framing of charges and trial for a juvenile committing an offence together with an adult, realising the psychological trauma such a juvenile might suffer (India 2000, Section 18). This Act categorically stated that 'no JCL shall be sentenced to death or life imprisonment, or committed to prison in default of payment of fine or in default of furnishing security, except that if s/he has attained sixteen years and has committed such offence that is serious in nature as per the Board, in which case s/he should be kept in place of safety' (India 2000, Section 16). All these changes gave effect to the CRC prescriptions that inter alia emphasised the social reintegration of children without resorting to judicial proceedings, and by adopting a child-friendly approach in the adjudication and disposition of matters in the best interest of children. However, the on-ground factual narratives of delinquent juveniles told a different story altogether, suggesting dismal law enforcement, and inadequate training of officials (Snehi 2004).

Thereafter, the Commissions for Protection of Child Rights (CPCR) Act (CPCR 2005) brought back the 'Children's Courts' (see National Commission for Protection of Child Rights 2005, Section 25) to provide speedy trial of offences against children. However, the Act was silent on the spatial specialisation of courtrooms to make them child-friendly, unlike earlier legislations. Its immediate trigger points seem to be the UN General Assembly Special Session on Children held in May 2002, and adoption of the National Charter for Children, 2003, by India. This was a positive step to protect child victims from the secondary victimisation of adult adversarial trial, embracing a victim-centred approach. The Act also appealed for specifying at least one children's court in the state or for each district. But as Kumari (2009a) argues, CPCR was confusing and silent on many pivotal aspects. The very next year, the JJA 2000 was amended by the JJAA 2006, which inserted a provision that had an override effect on the CPCR Act with respect to detention, prosecution, penalty or sentence of imprisonment of JCLs. ${ }^{19}$

The JJAA 2006 made JJ Board's constitution mandatory (India 2006, Section 6) for each district across the country, which was optional previously, thereby bringing regional deepening of the JJA 2000. It also did away with the confusion created by conflicting judicial decisions, which I will discuss in the next sub-section, over the definition of the JCL, by fixing the calculation of age on the date of commission of offence (India 2006, Section 4(iv)). Even the model Rules of 2007 framed by the central government, as per Kumari (2009b: 184), 'incorporate the beneficial, protective, and inclusive approach of JJA 2000 and contain many specific provisions to ensure its applicability to all children who were below the age of eighteen years on the date of offence whether undergoing trial or already found to have committed offence and undergoing imprisonment'(see Ministry of Women and Child Development [India] 2007, Rules 97-98).

Registration of sexual violence against children and women, which earlier used to get suppressed under the socio-cultural baggage of the comfort and unambiguity of the home, and stranger-outsider notions, were coming out vocally. This put forth the spatial 
dimension of the figure of the stranger as both distant and proximate (Moran and Skeggs 2004). It was argued in the parliamentary debate by Smt. Smriti Irani that out of $53 \%$ of children abused in the country, $50 \%$ had been abused by somebody they trusted or somebody in a position of responsibility (Rajya Sabha 2012). ${ }^{20}$ This grave situation was further aggravated by the rise in the alarming rate of sexual offences against children, and at the same time the fall in the conviction rate (Rajya Sabha 2012: 361). ${ }^{21}$ The reasons for this were stated to be the stigmatisation of the victim and the judicial delay (PSCR 2011), and the attempt by the society and families to keep quiet (Rajya Sabha 2012: 367).

There were several legislative faults in the IPC that were demanding a radical legislative action, such as the presence of gender bias in the relevant provisions, the absence of distinction between the child victim and adult victim of sexual offences, absence of specific categories of sexual offences committed against a male child, and absence of child-friendly procedure and courts. Considering these factors, in 2012, the Protection of Children from Sexual Offences Act (POCSO) was passed, which was gender-neutral, offence-centred and victim-centred legislation. The objective was to protect the right to privacy of the child by all means and through all stages of a judicial process involving the child victim. Further, the child was a 'party' to the proceedings, having the opportunity to fully participate and make his/her views known in conformity to the CRC norms. Therefore, special provisions for 'Procedures for recording statement of the child,' 'Special Courts' and 'Procedure and Powers of Special Courts and Recording of Evidence' were put in place (India 2012, Chapters VI, VII, VII).

The expressed provisions were drafted, mandatorily demanding the 'Special Public Prosecutor to communicate the question to the child victim through the judge,' 'creation of a child-friendly atmosphere by allowing a person to be in court in whom child has trust,' 'ensuring that child is not called repeatedly to testify in court,' 'prohibiting aggressive questioning and character assassination of child during trial,' 'non-disclosure of identity of the child during investigation or trial,' 'non-viewing of accused by the child-victim while testifying,' 'examination of child-victim at a place other than the court' (Delhi District Court 2014), ${ }^{22}$ and 'in-camera trials' (see India 2012, Sections 33, 36 and 37). Other discretionary provisions like 'permitting frequent breaks for child during the trial' and 'recording the statement of a child through video conferencing or by utilising single visibility mirrors or curtains or any other device' have also found a place (India 2012, Sections 33 and 36). This is an attempt to do away with what Spaulding (2012) has called the 'irreducible feature of adversarial legalism. Even the burden of proof under this Act has been put on the accused person rather than the child victim (India 2012, Section 29). Also, in the case of child offenders under the Act, it has been mentioned that $\mathrm{s} /$ he shall be dealt with under the JJA 2000 (India 2012, Section 34(1)).

This entire shift in the procedural framework in dealing with the child victims of sexual offences signals the significance of procedural justice in JJS specifically, and justice delivery generally. It echoes the influence of procedural justice theory, which, Jacobson, Hunter and Kirby (2016) argue, is concerned with factors which determine whether or not criminal justice institutions are perceived as legitimate and promote confidence in 
justice. It also shows the need to tone down the fear and awe of law reflected by the usual courtroom set-up and trial process to make it congenial for children.

The POCSO also increased the age of consent to sexual activity from sixteen to eighteen years. Hence, sexual activity, earlier treated as consensual, was criminalised, resulting in a significant surge in reporting of rape and kidnapping/abduction cases against men. Perhaps this was a step to make the age of majority uniform. However, this also reflected moral policing by the state. The Indian juvenile justice framework, though, had become more inclusive, robust and unambiguous. It suggested a progressive legislative understanding of children's rights, overcoming the gender bias that was present earlier. But while the legislative understanding seemed on the right track, the juridical understanding seemed conflicting, confusing, and tilted more towards an exclusionary approach and punitive action for children, specially the JCLs.

\section{Juridical understanding: oscillating between constructive and disruptive}

One of the most contentious issues of the Indian JJS was the determination of a child's age for the applicability of legislations, as both the JJA 1986 and JJA 2000 were silent on it. Which date should be considered, the date of commission of the offence, or the arrest, or the first production before the magistrate, or the submission of the charge sheet, or the beginning of the trial? The Supreme Court (SC) in Umesh Chandra (Supreme Court [India] 1982) held that the date of commission of the offence is relevant for determining the applicability of the Act. Later on, the division bench of the SC in Arnit Das (Supreme Court [India] 2000a) held that it was the age at the time of first production before a competent authority that determined applicability of the Act. This led to conflicting opinions. A five-judge bench of the SC sat to review Arnit Das (Supreme Court [India] 2000a) in Arnit Das (Supreme Court [India] 2001), and upheld the Umesh Chandra ruling by holding Arnit Das (Supreme Court [India] 2000a) as per incuriam. This confusion was clarified under the JJAA 2006, as already discussed.

'Nature of offence' also came to the fore in many cases when children committed serious crimes, i.e., crimes punishable with death or life imprisonment or under special statutes. The SC in Raghbir (1981) held that children's courts are competent to try all kinds of cases, which was not allowed prior to JJA 1986 (Kumari 2015). With respect to the offences being committed by children under special statutes like the Terrorist and Disruptive Activities (Prevention) Act (TADA), 1987, and the Narcotic Drugs and Psychotropic Substances Act (NDPS), 1985, the High Courts have held that special statutes will be applicable to the cases under them and not the JJA 1986 (Gauhati High Court 1992; Orissa High Court 1993). The SC later reversed this view as it affirmed applicability of the JJA even in the cases of TADA (Supreme Court [India] 2004) and NDPS (Supreme Court [India] 2000b). This was incorporated later by the JJAA 2006 (India 2006, Section 3(2)).

Another controversial issue was of the pending cases of children who were above sixteen but below eighteen, to whom JJA 1986 was inapplicable but the JJA 2000 became applicable. The issue of pending cases before non-juvenile courts dealing with boys who 
are above sixteen but below eighteen years of age on the date of commission of offence, and had not reached eighteen years on the date of enforcement of JJA 2000, i.e., 1 April 2001, came before the SC. The SC in Pratap Singh (Supreme Court [India] 2005) held that the JJA 2000 should be applicable to them, by considering them juveniles under it, and not the JJA 1986. This judgment, with regard to calculating age on the date of enforcement of the Act, took a narrow view of the applicability of the JJA 2000 (Kumari 2009b; Pande 2005). This decision brought in relevant changes to the JJA 2000 by the JJAA 2006. However, the JJAA 2006 also eliminated this narrowness by removing the limitation that the accused should be below eighteen years of age on the date of enforcement of the JJA 2000 for its applicability (Kumari 2009b). ${ }^{23}$ This brought in all those children under the protective umbrella of the JJA 2000 who were above sixteen but below eighteen years of age on the date of commission of offence, and gradually crossed the eighteen years bar on 1 April 2001, thereby giving the Act a retrospective effect.

Even after the 2006 amendment that settled the abovementioned issue, the SC seemed to be unaware of it, as it ignored the change and decided the issue of determination of age for the applicability of JJA 2000 through Pratap Singh (Supreme Court [India] 2007, 2008a). In later cases, though, the SC did consider the relevant provision and decided the matters accordingly, thereby, providing the much awaited clarification and relief since 2006 amendments (Supreme Court [India] 2008b, 2009). Considering the growth of the JJS framework since independence till the passage of POCSO 2012, there was clear indication that India has adopted a reformative form of justice for child delinquents. But, as I discuss in the next section, the rise in social movements for women's safety and violence against women, and populist punitiveness, amply precipitated by one incident, changed this entire legal topography.

\section{Back to square one? The gory incident, the JJA 2015 and its endangerments}

On the night of 16 December 2012, a brutal gang rape took place in a moving bus on the streets of Delhi, wherein five adults and a juvenile raped a 23-year-old girl (hereinafter Nirbhaya case). Thirteen days after the incident she died of her injuries. This ghastly incident incited public rage like never before, and people took to the streets in large numbers to showcase their anger. The protests, as Shakil (2013) has argued, were not the outcome of this single incident but mirrored the brewing discontent among the youth, cutting across sex and gender. She notes three aspects that were significant in the protests: 'ideologically loaded expression for freedom' of women, participation of men alongside women unlike in the past women's movements since 1970s, and unprecedented democratisation of participation in policing. However, some sections of society raised their voice in favour of enhanced punishment for crimes against women.

On 22 December 2012, the Verma Committee was appointed to suggest amendments to criminal law to sternly deal with incidents of sexual offences. On 26 December 2012, a Commission of Inquiry headed by Usha Mehra was set up to identify lapses, determine 
responsibility in relation to the incident, and suggest measures to make Delhi and the wider National Capital Region safer for women (Dhar 2012). On 1 January 2013, a thirteen-member special task force headed by the Union Home Secretary was established to look into women's safety issues in Delhi and review the functioning of the city police force on a regular basis (Zee News 2013).

Consideration of the Verma Committee report, which mentioned deep gender bias and neglect of women as root causes of sexual violence (Shakil 2013), led to the passage of the Criminal Law (Amendment) Act in March 2013, thereby bringing various legislative changes. However, the legislative response continued to reflect the gender bias plaguing the state (Shakil 2013). Although some women activists and many others went on to call for pre-modern forms of punishment like castration and the death sentence, which became global news (RT 2012; DW 2013; Nelson 2013), there seemed to be a populist punitiveness, i.e., notions which politicians could tap into and use for their own purpose which they believed to be the public's generally punitive stance. In later years, a few other cases like the Shakti Mills rape case in July 2013 and the Guwahati rape case in September 2013 caught the media's attention, as they too involved child delinquents.

This needs to be viewed from the wider perspective of social order phenomena of criminogenic circumstances. Children in particular are more influenced by their socio-economic environments. One also needs to bring in the legitimated defence of 'rotten social background' in the knowledge of the dire and blameless circumstances some accused defendants live in, and it is these circumstances which perhaps link to some offending pathways (Bazelon 1976; Duff and Green 2011). This is not something that can be ignored from a global South perspective, as its development has seen an increased gap in already divided socio-economic societal structures.

The emotional aftermath of the Nirbhaya case had a harsh bearing on the reformative nature of the juvenile justice jurisprudence of India, as it was pulled towards retribution (Sait 2016). The growing punitive stance may be realised from the fact that, firstly, the SC upheld the death sentence for the adult convicts of the Nirbhaya case, and secondly, there was clapping after this pronouncement from the populace present within the jam-packed courtroom, in the presence of the victim's parents. Also, there was public discontent with the child delinquent, who was 17 years and 10 months old, being treated under the JJA 2000 , and with his being 'merely' sent to a correctional home for three years. Rule of law seemed to be overpowered by the rule of emotions.

In 2014, a new central government came into power, and, in the race to be more concerned for women's safety and gender justice, showed the clear intention of passing a new JJA that would push the children in the sixteen-to-eighteen-years age group into the adult CJS for serious offences like rape. On 12 August 2014, the Juvenile Justice (Care and Protection of Children) Bill, 2014 was introduced in the Lok Sabha by Smt. Maneka Sanjay Gandhi, which was very much on the same line. The Rajya Sabha referred the Bill to a Parliamentary Standing Committee (PSC) for examination and report, which tabled the $264^{\text {th }}$ Report on 26 February 2015 (PSCR 2015). There were merely two parliamentary discussions on 6 and 7 May 2015, and the Lok Sabha passed the Bill on 7 May. The Rajya 
Sabha passed it on 22 December 2015. One can imagine the rush with which it was passed and the absence of rigorous debate on it from Pande's (2014) arguments for adopting a cautionary approach to such hasty reforms that sounded punitive rather than assimilative.

The causal connection of crime to a gendered notion of male demonisation is quite apparent here. Further, it should be noted that the Ministry, while drafting the statute, did not consider the suggestions of the stakeholders that it contended it was concerned about and paid heed to. This is revealed in a statement of the PSC:

A closer scrutiny of the suggestions reveals that major concerns of the stakeholders right from the rationale of repealing the Juvenile Justice Act of 2000 to the constitutional safeguards and India's commitment to UN Conventions, provisions relating to children in conflict with law and their protection, rehabilitative and reformatory nature of juvenile justice system have not been given due importance by the Ministry while drafting the proposed legislation (PSCR 2015: 15).

Further, the Ministry even overlooked the three-judges-bench decisions of the SC that were made on the issue of the child delinquent involved in the Nirbhaya case. In Salil Bali (Supreme Court [India] 2013b), the SC upheld the constitutional validity of the JJA 2000 , and stated that it was in tune with Indian constitutional provisions and international conventions. Considering that children were among the most vulnerable sections in any society, and upholding eighteen years as the age of juvenility, it was observed by the court that the age of eighteen had been fixed on account of article 1 of the CRC, National Policy for Children, 2013, and the understanding of experts in child psychology and behavioural patterns.

The Court further stated that till eighteen years of age, the JCL could still be redeemed and restored to mainstream society. On the disputed issue of pushing a group of children into the adult CJS, the court said that children between sixteen and eighteen years committing serious offences should also be dealt with within the JJA. Since such examples were not of such a proportion as to warrant any change in thinking, the court said it was probably better to try and re-integrate such children into mainstream society. The court also stressed the legislative intention of drafting a restorative, and not retributive, form of legislation.

In Dr. Subramaniam Swamy (Supreme Court [India] 2013a), the SC pronounced that the interpretation of the relevant provisions of the JJA 2000 in any manner by that court would not be confined to the first respondent (the child accused in the Nirbhaya case) alone but would have an effect on all juveniles who might come into conflict with the law, both in the immediate and the near future. Again, hearing the same petition on merits (Supreme Court [India] 2014), the SC dismissed the appeal filed by the petitioners, as well as the writ petition filed by the parents of the girl victim. It observed that if the legislature has adopted the age of eighteen as the dividing line between juveniles and adults, and such a decision is constitutionally permissible, the enquiry by the courts must come to an end. It further argued that there is a considerable body of world opinion that all persons under 
eighteen ought to be treated as juveniles, and separate treatment ought to be meted out to them so far as offences committed by such persons are concerned. It further stated that the avowed object was to ensure their rehabilitation in society and to enable the young offenders to become useful members of society later, which is well knit in the JJA 2000.

The JJA 2015, which came into force in January 2016, sought to bring a paradigm shift in juvenile justice jurisprudence, in spite of criticism that it was a step backwards, as it repealed the JJA 2000, which embodied a reformative approach towards juveniles under eighteen years, irrespective of the severity of their crime. A distinction has been made between children below and above sixteen years of age based on the gravity of the offence. It permits a child offender that has committed heinous offences ${ }^{24}$ to be 'tried' as an adult, based on the preliminary assessment by the Board, thereby bringing back the 'court,' done away with by the JJA 2000 (India 2015, Section 15). This provision requires JJB to assess whether a child above sixteen years of age who has committed a heinous offence has the physical and mental capability to commit the offence, along with circumstances in which he has committed the offence. This confers wide discretionary powers on the JJB (Pande 2014). It implies an assumption that the child has already committed the alleged offence. It has been argued that this enquiry amounts to a sentencing decision arrived at even before guilt is established, and denotes complete violation of the presumption of innocence, a central tenet of the CJS (PSCR 2015).

Exposing children to the adversarial adult CJS based on the nature of the offence is also in complete contravention of the CRC and the objective of JJA 2015 to adopt a child-friendly approach in the adjudication and disposal of matters in the best interests of children. Also, the subsequent trial does not seem to be a 'fair trial' as the preliminary inquiry has already branded the child as 'capable of committing crime.' Another significant deficiency of the JJA 2015 is the impossibility of accurate assessment of mental capacity/ maturity for the purpose of transfer of the trial of the child to the Children's Court. This would also be fraught with errors and arbitrariness and would allow inherent biases to determine which child was to be transferred to an adult court. The very presumption that persons between sixteen and eighteen years are competent to stand trial just as adults is also not free of gender bias (PSCR 2015: 59).

Other flaws of JJA 2015 are its constitutionally violative provisions that also transgress provisions of the CRC. Sections 2(33), 2(45), 2(54), which categorise offences into 'heinous', 'petty' and 'serious' offences, section 15 , which talks of preliminary 'assessment' into heinous offences by the Board, section 18(3), which mentions transfer of the child to the Children's Court for adult trial, and section 19, which discusses the power of the Children's Court of the JJA 2015, are in contravention of Indian constitutional provisions. ${ }^{25}$ Also, when the Indian legal system does not allow a child below eighteen years to drive, vote, enter into contracts, marry or own property, why should that child be subject to adult CJS, a point put forth by one of the interveners (Thukral and Asthana 2015) and also raised by the SC itself in the Salil Bali (Supreme Court [India] 2013b) case. The PSC has also argued that introducing children into the CJS amounts to violation of Article 21 , as the procedures contained therein are not commensurate with the requirements of children (PSCR 2015: 31). 
Further, a proviso of section 24(2), which allows retention of a juvenile's records, is also in violation of the right to privacy under Articles 16 and 40(2)(b)(vii) of the CRC, which applies to 'all stages of the proceedings' including 'from the initial contact with law enforcement up until the final decision by a competent authority, or release from supervision, custody or deprivation of liberty' Sections 19(3) and 20(2)(ii), which permit transfer of the child to prison clearly violates article 37(c) of the CRC, which talks of separation of juveniles from adults and does not mean 'that a child placed in a facility for children has to be moved to a facility for adults immediately after s/he turns eighteen.' Other than the abovementioned violations that the Act commits, there is a plethora of implementation flaws, as has been flagged in the PSCR (2015). There are insufficient investments, lack of an adequate number of JJBs and CWCs, lack of institutional infrastructure and trained personnel, lack of monitoring and coordination, and paucity of special juvenile police units. The interchangeable use of 'child' and 'juvenile' persists in the JJA 2015, and their use produces confusion in the scheme without serving any purpose. As the term 'juvenile' generally has a socially negative connotation carrying a stigma (PSCR 2015; Kumari 2009a), it seems better to replace the term 'juvenile' by 'child. ${ }^{26}$

Overall, the JJA 2015 seems to be a backward and pre-modern step in modern times, especially when the focus of general debate in the CJS is reformation and restoration. It forces child delinquents to jump off the ship of reformation and enter a vicious cycle of revenge and life-long stigmatisation. Its repercussion perhaps can be understood from the recent case of 'Ryan International', wherein a boy aged sixteen years, alleged of killing a 7-year-old boy, was first denied bail, and thereafter was ordered by the Board to be tried as an adult (Jha 2017). The social investigation and psychological reports, based on which the Board decided the matter, clearly mention various social factors and surroundings that might have led to his alleged act, but the Board ignored them outright. This signals a trend of many such cases of 'child (in)justice' that India might find its children trapped in, and paints a rather chilling picture for the future of child delinquents and child justice.

\section{Criminalisation and politics of 'violent' juvenile delinquents}

The JJA 2015 represents a compromise of the welfarism promise of the Indian state by the neo-conservative framework of moral culpability and punishment (Muncie and Hughes 2002). Rather than strengthening the JJA 2000 through robust infrastructural support and effective implementation, the government's response to 'violent' juvenile delinquency charts the path of justice as retribution, that too when many stakeholders ${ }^{27}$ had suggested otherwise.

\section{The politics of 'demonisation' and its repercussions}

This shift towards retribution as a state policing response to violent juvenile offending is based on gender bias, wherein the Indian state, with ample support of media driven by public sentiments, has demonised a particular group of male children as a potential 
threat to women and society at large. This has various repercussions. As the data in the next section will suggest, juvenile delinquents mostly belong to poor socio-economic and educational backgrounds. So, such a shift is far more likely to incarcerate these children, thereby pushing them further to the margins of the society. The presence of scientific evidence of higher vulnerability among adolescents to resort to violence, rather than their natural tendency (Kumari 2015), has also been noted. The state also seems to have tapped into nationalistic sentiments by connecting this issue to terrorism. It has often been said that this is also a step to negate the attempt by terrorist organisations to misuse the law by hiring children (PTI 2014). Even Kumari (2015) has argued that ' $\mathrm{t}$ ] here is a war of terror in the name of the war on terror, and it is no longer limited to the offenses of terrorism but has seeped into other areas of offending also.' In this regard, Justice Sodhi also cautioned:

We are a civilised nation and if we become barbaric by twisting our own laws, then the enemy will succeed in destroying our social structure. We should not allow that [...] (HT 2015).

With respect to the reasoning behind such a retributive act by the state, it seems arguably that the state could neither find an answer to the demand for freedom and gender-just laws for women, nor sustain the media pressure constructed around serious child offending. Kumari (2015) also mentions such pressure continuously being put on the legislature and judiciary. Such pressure was being piled up further because of the administrative abuse within the juvenile justice institutions and the perceived failure of rehabilitative programmes (Kumari 2015). Further, the lack of movements for child as an individual in India because of the persisting perception of them being in need of protection not in their own right has made the state's task of criminalisation of delinquent children easier. The move away from an all-inclusive and protective nature of the JJA 2000 jeopardises the future of many children. It is also quite apparent that the Ministry had very comfortably chosen to ignore and overlook the major stakeholders' views on the replacement of the JJA 2000 by JJA 2015. In spite of having sufficient resources, the state has failed to utilise them for the child community. Over the last couple of years, the share of Union budget for Indian children has been abysmally low, and on top of this, on a decline - from $4.8 \%$ in the 2012-2013 budget to 3.3\% in the 2016-2017 budget (Ganotra 2017; HAQ 2016).

\section{What do the numbers say? A critical analysis of NCRB's data}

The juvenile crime incidence in 2014 was 38 455, which decreased by $13.1 \%$ in 2015 , and then increased by $7.2 \%$ in 2016 to 35849 (NCRB 2016). Further, the educational background of the 44171 juveniles apprehended in 2016 suggests that 5412 juveniles of these were illiterate, 14501 were just able to complete their primary education, and 20014 juveniles could not even complete the tenth class (NCRB 2016). With respect to their family background, 1560 children were homeless, while 4550 were parentless. The birth registration in India at present is a meagre $70 \%$, which is again a threat in terms of proving the age of children in such cases conclusively. Even the narratives of the central government 
of an exponential growth in crimes against women to support the passage of JJA 2015 does not seem convincing enough when we glance at its recent figures from 2013 to 2016, except such growth in crimes against children:

Graph 1 - Number of crimes reported against women ${ }^{28}$ and children (between 2013 and 2016): year-wise breakup

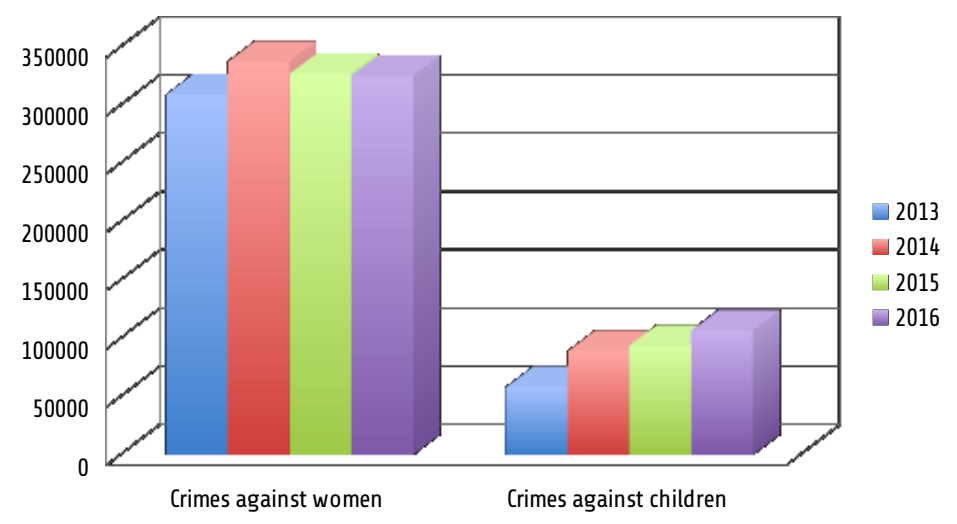

Source: NCRB $(2013,2014,2015,2016)$.

The number of serious offences (only four of such offences have been considered in the graph below) committed by children in the age group of sixteen to eighteen years does not appear to be on a continuous or sharp rise.

Graph 2 - Number of serious offences (Murder, Rape,, ${ }^{29}$ Kidnapping and abduction, Dacoity) reported to be committed by children in the age group of 16 years to below 18 years

(between 2013 and 2016): year-wise breakup



Source: NCRB $(2013,2014,2015,2016)$.

Even the percentage of juvenile crimes compared to total cognisable IPC crimes is meagre: $1.2 \%, 1.2 \%, 1.1 \%$, and $1.1 \%$ from 2013 to 2016 respectively, as shown in the graph below (NCRB 2013, 2014, 2015, 2016). It has also been argued that the number of child offenders in India is miniscule (PSCR 2015; Kumari 2015). 
Graph 3 - Total cognisable IPC crimes, total juvenile crimes, and the percentage of total juvenile crimes compared to total cognisable IPC crimes (between 2013 and 2016): year-wise breakup

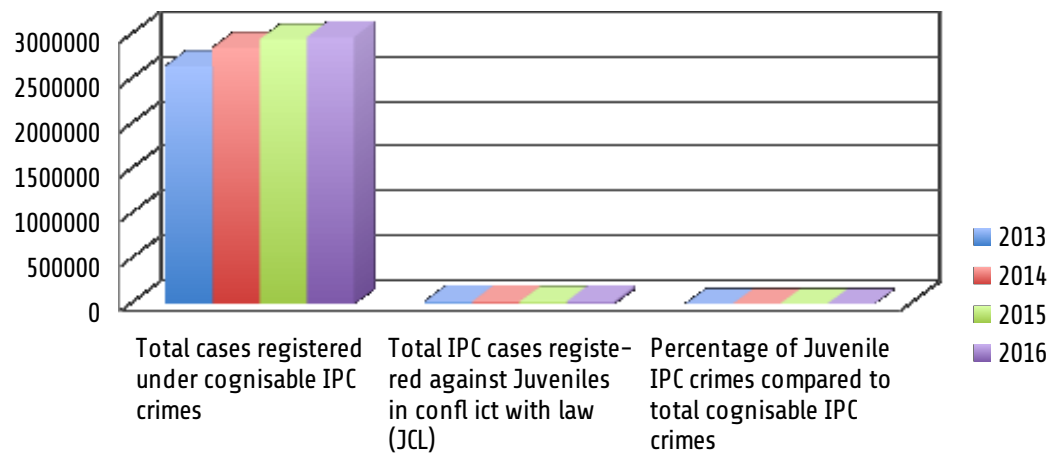

Source: NCRB $(2013,2014,2015,2016)$.

Further, the PSC had observed that there have been some lacunae in the way the NCRB's data was being collated, compiled, and analysed by the police, and that one should be circumspect about the need to decrease the age to sixteen years based on this data (PSCR 2015: 16). Even most cases of rape were either love or elopement cases where the girl's parents subsequently charged the boy with rape (PSCR 2015). The following table shows the percentages of children in the sixteen to eighteen years age group compared to the total child delinquents apprehended at 66.3\%, 73.7\%, 71.6\%, and 73.8\% (NCRB 2013, 2014, 2015, 2016), from 2013 to 2016 respectively. Even these numbers do not justify adoption of retributive measures, but rather recourse to reformative measures. It has been argued that the 'adolescent brain functions differently and that children in the age group 14 to 18 are particularly vulnerable to violent actions, are different from adults, and need to be treated differently' (Kumari 2015: 178).

Graph 4 - Percentages of children apprehended under IPC crimes in the sixteen to eighteen years age group compared to the total child delinquents apprehended under IPC crimes

(between 2013 and 2016): year-wise breakup

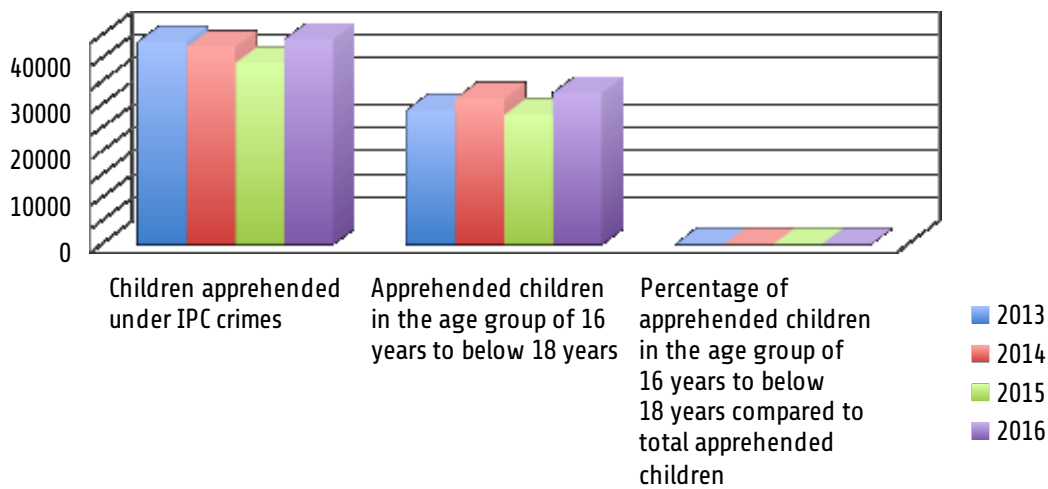

Source: NCRB $(2013,2014,2015,2016)$. 
Even the NCRB's data needs to be cautiously considered, as the PSC had argued that the data has presented an entirely different scenario. It has noted:

NCRB data was based on FIRs [First Information Reports] and did not provide information on the conviction of children in the age group of sixteen to eighteen years or otherwise. It is true that FIR/ complaint was merely an information regarding occurrence of an offence. The Committee is of the firm opinion that increased reporting of crime against children in the specific age-group should not necessarily lead to assumption of increased conviction of juvenile in the crime. The realistic figure of involvement of juvenile in heinous crime needs to be based on completion of investigation, filing of final report by the police before the court and pronouncement of judgment (PSCR 2015: 27-28).

When contemplating the sixteen to eighteen age group of child delinquents who were apprehended - 44171 in the year 2016 - emphasis should also be given to the 1082 girls within this group (NCRB 2016). They are also being pushed into the CJS in the guise of facilitating retribution for the male child delinquents.

\section{Epilogue: in pursuit of restoring 'child justice'}

I have mapped the shift in the epistemic understanding of the different ontological dimensions of JJ jurisprudence from the colonial era to the present time. In this entire journey, the embeddedness of the issue of gender has been quite apparent. Be it in understanding the factor of age in deciding the nature of treatment for child delinquents or the nature of the offence committed, gender bias has crept into the thought process and policing of the state. I have also debunked the myth of rising serious juvenile offending. Rather than reflecting on its poor response to the social movements for women's safety, and poor implementation of the inclusive JJA 2000, the state's response has been vindictive. In order to hide these failures, the state has responded in an irrational manner, which imperils the safety of both women and children.

The entire philosophy of juvenile jurisprudence is centred on the quality of restoration, rehabilitation and reform, rather than incarceration and retribution. There are, no doubt, several factors that have combined to undermine the optimistic ideal of a reformative penality. However, the needs of the hour are better implementation of juvenile justice legislations, more public awareness of juvenile criminality, improvement of the monitoring and accountability mechanism of the institutions involved in the JJS, the presence of performance appraisal procedures, and augmentation of children's capacity building (Supreme Court [India] 2017). ${ }^{30}$ It also needs to be acknowledged simultaneously that the undue emphasis on juridical reform for solving complex problems without touching the actual reality in Indian society is a specific ontological condition. 
It has been categorically argued that 'an all-inclusive protective and rehabilitative approach is the best way to deal with children, including and especially adolescents who commit serious offenses' (Kumari 2015: 178). Child justice needs to be reclaimed but with an understanding of the incapacity of legal reform to render justice unilaterally because of its embedded constraints, and by recognising the politicisation and limits of rendering of justice by judiciary in contemporary India. Only if there is social transformation with gender justness, can children be treated with compassion to channelise their reintegration into society. We need to understand that a child offender is not really an offender, but a victim (Supreme Court [India] 2017). ${ }^{31}$ The way we treat our children also determines how we want the world to see us as a political and social community. The current epistemic shift in the JJ framework is rooted in an epistemological inadequacy coupled with superficial understanding of the very diverse and extremely intersectional nature of the Indian society. Let us not forget that 'the litmus test of justice or injustice in any society is how it treats its poor and powerless' (O'Kane 2002: 698).

\section{Notes}

1 It is an irony, and seems self-contradictory, to use 'juvenile' in the title of the paper, because the paper, as it progresses, argues for complete replacement of 'juvenile' by 'child' in all its usages in the context of child justice globally. The purpose it serves here is to merely resonate with the present nature of its usage.

2 Considering only the legislations pertaining to children as offenders/victims of crimes, there has been a plethora of legislations passed during this period, such as the Juvenile Justice (Care and Protection of Children) Act 2000 (India 2000), the Commission for Protection of Child Rights (CPCR) Act 2005, the Juvenile Justice (Care and Protection of Children) Amendment Act 2006 (JJAA 2006), the Juvenile Justice (Care and Protection of Children) Amendment Act 2010 (JJAA 2010), the Protection of Children from Sexual Offences Act 2012 (POCSO) and the Juvenile Justice (Care and Protection of Children) Act 2015 (JJA 2015).

3 Particularly, the Convention on the Elimination of All Forms of Discrimination against Women (CEDAW) 1979, and the UN Convention on the Rights of the Child (CRC) 1992.

4 To avoid confusion, in this paper, 'child' shall mean a natural person below the age of eighteen years, and 'juvenile' shall mean the same, unless expressly mentioned. Surprisingly enough, the JJA 2015 defines 'child' and 'juvenile' quite similarly but puts them under different provisions even after the red signal by the Parliamentary Standing Committee (PSC). Section 2(12) of the Act states that 'child' means a person who has not completed eighteen years of age, while section 2(35) says that 'juvenile' means a child below the age of eighteen years. The central government also failed to learn from within the country, as section $2(\mathrm{~m})$ of the Jammu and Kashmir Juvenile Justice (Care and Protection of Children) Act 2013 defines 'juvenile' or 'child,' in one provision, as 'a person who has not completed eighteenth year of age.'

5 This borrowing is sufficient evidence of the nature of societies that is being broadly referred to in this work. However, its locus is the juvenile justice system in India, particularly, child delinquency.

6 The UNCRC in its concluding observations on the combined third and fourth periodic reports of India has shown serious concern on the issue of the minimum age of criminal responsibility still being set at seven years, and urged it to give effect to the Juvenile Justice Rules of 2007, which establish the minimum age of criminal responsibility at 18 years, and to maintain the minimum age at an internationally acceptable level.

7 It is important to note here that 'the presumption that a child under fourteen was doli incapax fell, as the recorder of Birmingham observed in 1852, "into desuetude" (Magarey 2002: 116).

8 Interestingly, the IPC had been silent about the case where a child of 'seven' years is accused of a crime.

9 Section 4(a) of the Reformatory Act, 1897 defined 'youthful offender' as a boy below fifteen years of age. 
10 It was adopted on 26 September 1924 by the League of Nations.

11 The CRC is the first human rights treaty that combines the two generations of human rights in one single text, by which it explicitly emphasises the indivisibility of human rights.

12 Article 39(e) and (f) of the Indian Constitution, 1950 provide:

(e) that the health and strength of workers, men and women, and the tender age of children are not abused and that citizens are not forced by economic necessity to enter avocations unsuited to their age or strength; (f) that children are given opportunities and facilities to develop in a healthy manner and in conditions of freedom and dignity and that childhood and youth are protected against exploitation and against moral and material abandonment.'

13 Article 15(3) of the Indian Constitution, 1950 states: 'Nothing in this article shall prevent the State from making any special provision for women and children.' It empowers the State to make any special provision for children, as this provision prohibits discrimination by State on grounds of religion, race, caste, sex or place of birth, but not of 'age.'

14 This resulted from the Supreme Court's decision in Sheela Barse v. Secretary, Children's Aid Society (Supreme Court [India] 1986).

15 Rule 8 of the Beijing Rules provided for protection against the process of labelling.

16 India agreed in principles to all articles except those pertaining to child labour.

17 The opening statement of the JJA 2000 (India 2000) mentions it in detail.

18 In this case, the court quashed the entire proceedings of the case because it was held on court premises, which was prohibited under the law, and the question of child-friendly judicial space came to the fore while the court decided the matter in favour of the juvenile to an extent that it ordered fresh proceedings to be held.

19 'Notwithstanding anything contained in any other law for the time being in force, the provisions of this Act shall apply to all cases involving detention, prosecution, penalty or sentence of imprisonment of juveniles in conflict with law under such other law' (see India 2006, section 3(ii)).

20 This is the report from the 'Study on Child Abuse, 2007,' which was made by the Ministry of Women and Child Development in 13 states of India.

21 Statement of Smt. Krishna Tirath, Minister of State of the Ministry of Women and Child Development, Government of India.

22 For instance, in this case, the testimony of an eight-year-old girl was recorded in a chamber annexed to the courtroom while ensuring that the accused could hear her testify.

23 An explanation to section 20 of the JJA 2000 was added by the JJAA 2006 (see India 2006, section 14).

24 It includes the offences for which the minimum punishment under the Indian Penal Code or any other law for the time being in force is imprisonment for seven years or more. See section 2(33), the JJA 2015. There are 20 offences under the IPC 1860 and 26 offences under Special \& Local Laws that can be categorised as 'heinous offences' under the JJA 2015 (India 2015).

25 They violate articles 14 (equality before the law and equal protection of laws), 15(3), 20(1) (ex-post facto law), and 21 (Protection of life and personal liberty).

26 The reasons given by the Ministry of Women and Child Development not to replace 'juvenile' by 'child' in the title of the Act have been that the title has been well understood by the stakeholders, and a new title may result in confusion thereby hampering the effective implementation of the law. Even the PSC had recommended that the title of the Bill should be changed to Justice for Children (Care and Protection of Children) Bill, 2014. I would second this suggestion, as replacing 'juvenile' by 'child' throughout the legislation would send a loud and clear message about the understanding of the Act as producing a separate reformative criminal justice system for children and an appropriate take on child justice in India.

27 The representatives of NGOs Tulir-Centre for the Prevention and Healing of Child Sexual Abuse, Save the Children, and Butterflies proposed against criminalisation of child delinquents.

28 It was only in 1995 that the NCRB started recording statistics on crimes specific to women as a separate chapter (Baxi 2013). 
29 'It was not until 1971 that the National Crime Records Bureau's (NCRB) annual publication, Crime in India, provided official statistics on the number of cases of rape reported in the country' (Baxi 2013: 384).

30 The SC issued various directions in this case to the Union government and the governments of the states and Union territories.

31 The SC stressed the extension of benefits envisaged for 'children in need of care and protection' under section 2(14) of the JJA 2015 to all those children who in fact require state care and protection.

\section{References}

Baxi, Pratiksha. 2014. Public Secrets of Law: Rape Trials in India. New Delhi: Oxford University Press.

Bazelon, D L. 1976. 'The morality of the Criminal Law. Southern California Law Review 49: 385-405.

Boise, S de. 2013. 'Patriarchy and the "crisis of masculinity."' At http://www.newleftproject.org/ index.php/site/article_comments/patriarchy_and_the_crisis_of_masculinity\#_edn8 [Accessed 9 January 2018].

Carlen, P. 1976. 'The staging of magistrates' justice.' British Journal of Criminology 16 (1): 48-55.

Dados, N and R Connell. 2012. 'The global South.' Contexts 11 (1): 12-13.

Delhi District Court. 2014. State v. Badku. Judgment, 8 January. At https://indiankanoon.org/ doc/13193278/ [Accessed 30 December 2017].

Department-Related Parliamentary Standing Committee on Human Resource Development [India]. 2011. 240 th Report on the Protection of Children from Sexual Offences Bill, 2011. New Delhi.

Delhi.

2015. 264 ${ }^{\text {th }}$ Report: The Juvenile Justice (Care and Protection of Children) Bill, 2014. New

Dhar, A. 2012. 'Commission to suggest steps to make Delhi safe for women.' The Hindu. 26 December.

Duff, A, L Farmer, S Marshall and V Tadros (eds). 2004. The Trial on Trial (Volume 1): Truth and Due Process. Oregon: Hart Publishing.

Duff, R A and S Green (eds). 2011. Philosophical Foundations of Criminal Law. Oxford: Oxford University Press.

DW. 2013. 'India considers chemical castration for rapists.' 1 January. At http://www.dw.com/en/ india-considers-chemical-castration-for-rapists/a-16490842 [Accessed 26 December 2017].

Ganotra, K. 2017. 'Budget 2017-18 disheartening for children.' DownToEarth, 2 February. At http:// www.downtoearth.org.in/blog/budget-disheartening-for-children-56953 [Accessed 10 January 2018].

Gauhati High Court. 1992. Shri Jagadish Bhuyan v. State of Assam. Judgment, 21 May.

HAQ: Centre for Child Rights. 2016. Budget for Children 2016-2017: Not even halfway through its demographic dividend. New Delhi. At http://haqcrc.org/wp-content/uploads/2016/03/budget-for-children-2016-17-not-even-halfway-through-its-demographic-dividend1.pdf [Accessed 12 January 2018].

Hindustan Times. 2015. 'Is Pak militant Naved a juvenile, or is he just being clever?' Hindustan Times, 8 August. At http://www.hindustantimes.com/india/is-pak-militant-naved-a-juvenile-or-is-he-just-being-clever/story-eORK3nedNuOEpf6m31nsKK.html\%0A [Accessed 25 December 2017]. 
Horrocks, R. 1994. Masculinity in Crisis: Myths, Fantasies and Realities. London: The Macmillan Press Ltd.

India. 1860. Indian Penal Code. New Delhi.

1960. Children Act. New Delhi.

1986. Juvenile Justice Act (JJA) 1986. New Delhi.

2000. Juvenile Justice Act (JJA) 2000. New Delhi.

2006. Juvenile Justice (Care and Protection of Children) Amendment Act (JJAA) 2006. New

Delhi.

Delhi.

2010. Juvenile Justice (Care and Protection of Children) Amendment Act (JJAA) 2010. New

2012. Protection of Children from Sexual Offences Act (POCSO). New Delhi.

2015. Juvenile Justice Act (JJA) 2015. New Delhi.

Jaamdar, S. 1995. 'Bringing justice to juveniles: Extension of poverty alleviation programmes.' Economic and Political Weekly 30 (29): 1833-1835.

Jacobson, J, G Hunter and A Kirby. 2016. Inside Crown Court: Personal Experiences and Questions of Legitimacy. Bristol: Policy Press.

Jha, B. 2017. 'Ryan murder case: Why juvenile will be tried as adult.' The Times of India, 21 December. At https://timesofindia.indiatimes.com/city/gurgaon/ryan-murder-case-why-juvenile-will-be-tried-as-adult/articleshow/62186930.cms?utm_source=email\&utm_medium=Email\&utm_ campaign=TOIMobile [Accessed 28 December 2017].

Kulkarni, M N. 1994. 'Justice for “Delinquents.” Economic and Political Weekly 29 (26): 1575.

Kumari, V. 1993. Treatise on the Juvenile Justice Act, 1986. New Delhi: Indian Law Institute. 2004. The Juvenile Justice System in India: From Welfare to Rights. New Delhi: Oxford University Press.

2009a. 'Juvenile justice: Securing the rights of children during 1998-2008.' NUJS Law Review 2: $557-572$.

2009b. 'Quagmire of age issues under the Juvenile Justice Act: From inclusion to exclusion.' Journal of the Indian Law Institute 51 (2): 163-186.

2015. 'Juvenile Justice in India.' In F E Zimring, M Langer and D S Tanenhaus (eds), Juvenile Justice in Global Perspective. New York: New York University Press, pp. 145-197.

Madras High Court. 2012. Mohammad Irfan v. The Inspector of Police. Judgment, 20 June. At https:// indiankanoon.org/doc/148846029/ [Accessed 28 December 2017]

Magarey, S. 2002. 'The invention of juvenile delinquency in early nineteenth-century England.' In J Muncie, G Hughes and E McLaughlin (eds), Youth Justice: Critical Readings. London: Sage Publications Ltd., pp. 115-122.

Ministry of Women and Child Development [India]. 2007. Rules under the Juvenile Justice (Care and Protection of Children) Act 2000 (56 of 2000) (as amended by the Amendment Act 33 of 2006) to be administered by the States. New Delhi.

Moran, L J and B Skeggs. 2004. Sexuality and the Poitics of Violence and Safety. 1st ed. London: Routledge. 
Morrison, W. 1995. Theoretical Criminology: From Modernity to Post-Modernism. London: Cavendish Publishing Limited.

Muncie, J and G Hughes. 2002. 'Modes of Youth Governance: Political Rationalities, criminalization and resistance.' In J Muncie, G Hughes and E McLaughlin (eds), Youth Justice: Critical Readings. London: Sage Publications Ltd., pp. 1-18.

National Commission for Protection of Child Rights (NCPCR) [India]. 2005. Commission for Protection of Child Rights Act 2005. New Delhi.

National Crime Records Bureau (NCRB). 2013. Crime in India - 2013. Delhi.

. Crime in India - 2014. Delhi.

. Crime in India - 2015. Delhi.

. Crime in India - 2016. Delhi.

Nelson, S C. 2013. 'Gulabi Gang, Indian women's movement calls for castration of gang rapists.' At http://www.huffingtonpost.co.uk/2013/01/06/gulabi-gang-indian-castration-gang-rapists-_n_2419629.html [Accessed 4 January 2018].

O'Kane, C. 2002. 'Marginalized children as social actors for social justice in South Asia.' British Journal of Social Work 32 (6): 697-710.

Orissa High Court. 1993. Antaryami Patra v. State of Orissa. Judgment, 26 March.

Pande, B B. 2005. 'Setting the Juvenile Justice Course Right: A Critique of Pratap Singh v. State of Jharkhand.' Supreme Court Cases (Journal) 6: 1.

. 2014. 'In the name of Delhi gang rape: The proposed tough Juvenile Justice Law reform initiative.' Journal of National Law University 2: 145-166.

Pratt, John. 2007. Penal Populism. London: Routledge.

Punjab-Haryana High Court. 2000. Raj Pal Singh v. State of Haryana. Judgment, 26 April.

Rajya Sabha. 1960. Rajya Sabha Debates- 15 February. At http://rsdebate.nic.in/bitstream/123456789/561487/1/PD_28_15021960_6_p683_p766_11.pdf [Accessed 8 January 2018].

2012. Rajya Sabha Debates- 225th Session, 10 May. At http://rsdebate.nic.in/bitstream/123456789/603084/1/ID_225_10052012_p361_p391_29.pdf [Accessed 10 January 2018].

RT. 2012. 'Gang-rape epidemic: India mourns victim, proposes chemical castration for offenders.' 30 December. At https://www.rt.com/news/delhi-chemical-castration-rape-092/ [Accessed 28 December 2017].

Sait, N A. 2016. 'Juvenile Justice Act 2015; an emotional aftermath of the dreaded "Nirbhaya Incident"; a step backward.' Live Law, 11 March. At http://www.livelaw.in/juvenile-justice-act-2015-emotional-aftermath-dreaded-nirbhaya-incident-step-backward/ [Accessed 23 December 2017].

Sen, S. 2004. 'A Separate Punishment: Juvenile Offenders in Colonial India.' The Journal of Asian Studies 63 (1): 81-104.

2005. Colonial Childhoods: The Juvenile Periphery of India, 1850-1945. London: Anthem Press.

Shakil, A. 2013. 'Protests, the Justice Verma Committee and the Government Ordinance.' Economic \& Political Weekly 48 (06). At https://www.epw.in/journal/2013/06/web-exclusives/protests-justice-verma-committee-and-government-ordinance.html [Accessed 8 January 2018]. 
Snehi, Y. 2004. 'State and Child Justice: Stories of Delinquent Juveniles.' Economic and Political Weekly 39 (41): 4512-4515.

Spaulding, N W. 2012. 'The Enclosure of Justice: Courthouse Architecture, Due Process, and the Dead Metaphor of Trial.' Yale Journal of Law \& the Humanities 24 (1): 311-343.

Supreme Court [India]. 1981. Raghbir v. State of Haryana. Judgment, 8 September.

. 1982. Umesh Chandra v. State of Rajasthan. Judgment, 2 April.

. 1986. Sheela Barse v. Secretary, Children's Aid Society. Judgment, 20 December.

2000a. Arnit Das v. State of Bihar. Judgment, 9 May.

2000b. Raj Singh v. State of Haryana. Judgment, 16 February.

2001. Arnit Das v. State of Bihar. Judgment, 28 August.

2004. Madan Singh v. State of Bihar. Judgment, 2 April.

2005. Pratap Singh v. State of Jharkhand. Judgment, 2 February.

2007. Jameel v. State of Maharashtra. Judgment, 16 January.

2008a.Balu@ Bakthvatchalu v. State of Tamilnadu. Judgment, 12 February.

2008b. Jayasingh v. State by Inspector of Police. Judgment, 15 February.

2009. Hari Ram v. State of Rajasthan \& Anr. Judgment, 5 May.

2013a. Dr. Subramanian Swamy \& Ors. v. Raju through Member Juvenile Justice Board \& Anr.

Judgment, 22 August.

2013b. Salil Bali v. Union of India. Judgment, 17 July.

.2014. Dr. Subramanian Swamy \& Ors. v. Raju through Member Juvenile Justice Board \& Anr. Judgment, 28 March.

2017. Re: Exploitation of Children in Orphanages in the State of Tamil Nadu v. Union of India \& Ors. Judgment, 5 May.

The Indian Express. 2014. 'Claim to be juvenile to escape law: LeT tells its cadre.' At http://indianexpress.com/article/india/india-others/claim-to-be-juvenile-to-escape-law-let-tells-its-cadre/ [Accessed 27 December 2017].

Thukral, E G and A K Asthana. 2015. 'Children's Rights in Litigation: Use of the CRC in Indian Courts.' In T Liefaard and J E Doek (eds), Litigating the Rights of the Child. New York/London: Springer, pp. 31-51.

UN Treaty Collection. 2018. 'Convention on the Rights of the Child.' At https://treaties.un.org/ pages/viewdetails.aspx?src=treaty\&mtdsg_no=iv-11\&chapter=4\&lang=en\#EndDec [Accessed 12 January 2018].

Verhellen, E. 2015. 'The Convention on the Rights of the Child: Reflections from a historical, social policy and educational perspective.' In Wouter Vandenhole, Ellen Desmet, Dider Reynaert and Sara Lembrechts (eds), Routledge International Handbook of Children's Rights Studies. London: Routledge, pp. 43-59.

Zeenews. 2013. 'Government constitutes task force to look into women's safety issues.' 2 January. At http://zeenews.india.com/news/nation/special-task-force-to-look-into-safetyissues-of-women_820124.html [Accessed 2 January 2018]. 


\section{Acknowledgements}

The comments from the two anonymous reviewers and Natália Félix de Souza, the guest editor, were very helpful, and indeed contributed to enriching the paper. The paper has also benefited from the comments of the audience at the SLSA Annual Conference, 27-29 March 2018, University of Bristol, Bristol, UK.

\section{About the author}

Shailesh Kumar is a Commonwealth Scholar, pursuing his $\mathrm{PhD}$ at the School of Law, Birkbeck, University of London. He is an alumnus of Chanakya National Law University (CNLU) and NALSAR University of Law and holds an M.Phil. from the Centre for the Study of Law and Governance, Jawaharlal Nehru University, New Delhi. His current research work focuses on the aesthetics of criminal courts in India from an access-to-justice perspective. His work on the art and architecture of the Supreme Court of India was published in the International Journal for the Semiotics of Law. 


\section{Mudando a Epistemologia da Justiça Juvenil na Índia}

Resumo: A concepção de justiça juvenil teve sua raiz ontológica na internalização da infância e construção das crianças como uma classe social distinta. A visão eurocêntrica de crianças como possuidoras de direitos que informa a Convenção de Direitos das Crianças das Nações Unidas (CDC) (1989) transformou a epistemologia da justiça juvenil. A Índia, que ratificou a CDC em 1992, definiu 'criança' uniformemente, independentemente do sexo, ao contrário do passado, desafiando assim sua subjetividade da 'criança do sexo feminino.' Tal emergência de uma nova modalidade de justiça juvenil que eu vejo como a mudança epistêmica não durou muito e um incidente sangrento, junto com a demonização midiática das crianças do sexo masculino, e o crescente descontentamento social da segurança das mulheres, mudou seu panorama. Esse artigo estabelece uma análise sobre o papel do gênero na jurisprudência da justiça juvenil desde o período colonial até o presente momento. Refletindo sobre a punitividade populista em jogo, ele fala sobre a pobreza do estado indiano acerca do entendimento sobre os direitos das crianças. Mapeando as dimensões legislativas, jurídicas e políticas da jornada do cenário da justiça juvenil na Índia, o artigo mostra como construção da noção de gênero de um grupo particular de delinquentes do sexo masculino resultou na virada punitiva do sistema de justiça juvenil na Índia. Isso desdobra ainda mais a potencialidade de suas repercussões, e oferece razões para que uma resposta retributiva do Estado seja um retrocesso na reforma de delinquentes juvenis. No geral, narra a história de um fracasso do sistema político em lidar com uma importante problema social, o qual pode atuar como uma lição a ser aprendida com respeito à estrutura de governança infantil, tanto para países no Sul da Ásia quanto para o Sul Global.

Palavras-chave: justiça juvenil; delinquente do sexo masculino; Índia; punitividade populista; preconceito de gênero; Corte Suprema da Índia; ofensa grave.

Received on 30 January 2018, and approved for publication on 6 November 2018. 